\title{
INTERTEXTUAL PALLETTE IN WILLIAM HOWARD GASS'S “THE TUNNEL”: RAINER MARIA RILKE'S LITERARY PARALLELS IN THE NOVEL
}

\author{
Serhii Sushko, \\ Donetsk Institute \\ Private Joint-Stock Company “Higher Education Institution \\ 'Interregional Academy of Personnel Management'" \\ Kramatorsk, Ukraine \\ erehwonado@gmail.com \\ ORCID iD 0000-0001-6954-0046
}

\begin{abstract}
The given article presents an overview and initial analysis of the manifold influences of R. M. Rilke's poetry and prose on William H. Gass's "The Tunnel". The American writer and literary scholar W. H. Gass repeatedly acknowledged Rilke's profound impact on his novel. Undertaking our research of the particular manifestations of Rilke's "presence" in "The Tunnel", we are naturally guided, and motivated, by a challenging task of specifying those fragments and chunks of the text as well as underlying ideas and concepts which were borrowed from Rilke, which could be traced back to his works. Ou opening research into the problem specified has brought forth the following results. Intertextual links of "The Tunnel" are manifold, the Rilkean parallels being profound, versatile and fruitful. The core of Rilkean influence is formed by sharing much from the poetics of Rilke's novel "The Notebooks of Malte Laurids Brigge" - an artist's vision, forms of delineating things (Dinge), some plot lines and narratives, a device of inserted stories, auto fictionality, philosophically charged, reflexive prose writing, autobiographical narrative. Besides, "The Tunnel" features dozens of parallels with Rilke's poetical works.
\end{abstract}

Key words: intertextual, borrowings, experimental fiction, description / delineation, parallel / convergence, thing (Das Ding), poetics, philippic, allusion, reminiscence.

\section{Сушко С.O.}

Інтертекстуальна палітра у романі Вільяма Говарда Гасса «Тунель»: літературні паралелі Райнера Марії Рільке у романі

У статті проаналізовано чинники інтертекстуального впливу роману Р.М. Рільке «Нотатки Мальте Лаурідса Брігzе» на роман американського письменника В.Г. Гасса "The Tunnel". Meту та актуальність нашого дослідження визначає методологічна дочільність аналізу інтертекстуальної палітри твору Гасса саме у площині виокремлення конкретних фрагментів твору Рільке, відлуння яких знаходимо у романі Гасса. Роман «Тунель» поділяє багато рис поетики «Нотаток»-художню перспективу, форми зображення речей, окремі сюжетні лінії, засіб вставних новел, автофікціональність.

Ключові слова: інтертекстуальний, запозичення, експериментальна проза, опис, паралель/збіг, матеріальний предмет, поетика, філіппіка, алюзія, ремінісценція.

\section{Сушко С.A.}

\section{Интертекстуальная палитра в романе Вильяма Хауэрда Гасса «Тоннель»: литературные паралле- ли Райнера Марии Рильке в романе}

В статье проанализированы факторы интертекстуального влияния романа Р.М. Рильке «Записки Мальте Лауридса Бригге» на роман американского писателя В.Х. Гасса "The Tunnel". Цель и актуальность нашего исследования определяет методологическая челесообразность анализа интертекстуальной палитры романа Гасса именно в плоскости определения конкретных фрагментов произведения Рильке, отражение которых находим в романе Гасса. Роман "Тоннель" реализует многое из новаторской поэтики «Записок» - художественную перспективу, формы изображения вещей, отдельные сюжетные линии, прием вставных новелл, автофикциональность.

Ключевые слова: интертекстуальный, заимствование, экспериментальная проза, описание, параллель / совпадение, материальный предмет, поэтика, филиппика, аллюзия, реминисценция.

\section{Introduction}

Both men of letters, an American writer and literary scholar William Howard Gass and a Bohemian-Austrian poet and prose writer Rainer Maria Rilke, tapped new sources in literary representation by way of introducing new themes, 
topics and objects as well as by expanding and enriching a set of descriptive and expr ssive means. While Rilke's poetic versatility manifested itself, among other things, in rethinking and reconceptualization of an individual's relationship with the sublime transcend forces ("Who, if I cried out, would hear me in the reach of Angels?") and in infusing new expressiveness into the blank verse ("...Perhaps a tree on some hillside is ours to see / anew each day. Perhaps there remains the street / of yesterday..."), W. H. Gass excelled himself in an astonishingly coherent fusion of fictional narrative and essayistic form (in The Tunnel) and in exploring and revealing the new expressive force and power in the tandard English wordstock ("The true alchemists do not change lead into gold; they change the world into words." from Omensetter's Luck).

William H. Gass made a significant contribution into the study of R. M. Rilke's poetics. His lifelong admiration and reverence of Rilke was crowned in 1999 by publishing Reading Rilke. Reflections on the Problems of Translation. The book marked a new step in the Rilkean studies not only for its scholarly depth but also due to the fact that William Gass had himself translated Rilke's Duino Elegies, having thus added his own poetical vision and interpretation of the elegies to nearly twenty available English translations of them. (J. M. Coetzee counted nineteen English translations, as of 1999, preceding Gass's Duino Elegies. "A twentieth, by Edward Snow, is due shortly." [4]

The Tunnel went out of print in 1995 but much long before that it had come to be regarded as W. H. Gass's Magnum Opus, the writer himself promoting it as such in numerous interviews, by way of naming it the work-in-progress and letting sections from it get published separately ("Parts of The Tunnel, his novel in progress, have been appearing since 1969."). It was still at that work-in-progress stage that W. Gass kept discussing the Rilkean content in it. As far back as 1976, nineteen years before The Tunnel was released, William Gass expressed his intention, in respect of The Tunnel, to incorporate Rilke's mode of writing into his own:

"Intellectually, Valéry is still the person I admire most among artists I admire most; but when it comes to the fashioning of my own work now, I am aiming at a Rilkean kind of celebrational object, thing, Ding." [11]

Proceeding from these considerations we define the threefold objective of the given research: to establish the permanence of Gass's interest in Rilke's literary output; to look for those chunks of W. H. Gass's The Tunnel which bear the marks of intertextual relationship with R. M. Rilke's The Notebooks of Malte Laurids Brigge as well as with a number of Rilke's poems; to analyse the patterning of Rilke's literary parallels and borrowings in the novel of W. H. Gass for the shifts and changes these borrowings underwent. The last instance obviously requires a research of its own but already in this paper we regard it as an indispensable part and aspect of treating the intertextual terrain of W. Gass's The Tunnel.

The topicality of the research undertaken is related to the ever prioritized scholarly task of finding that multitude of sources and influences which helped the author create his masterpiece. More specifically, the topicality of the present research lies in the necessity to account for the numerous allusions and reminiscences from Rilke and Rilke's biography which are so generally scattered, rather carefully incorporated into, throughout The Tunnel. Naturally, both readers and scholars were and continue to be intrigued by William Gass's paying the highest tribute ever to Rilke, the writer and personality, for shaping his, Gass's, authentic writing method and style.

The innovative, or novel, aspects of the present paper can be seen in an attempt to specify particular concordances of certain plot lines, narratives, descriptions, techniques, authorial transparency in the text, underlying philosophies. Likewise, a brief initial step is taken, on our part, to treat the metaphoricity of some of the borrowings from Rilke, in particular the famous Rilkean metaphor 'An Outcast on the Mountains of the Heart' (it being, in the first place, the title of his poem) taken by W. H. Gass to name his final philippic in the novel.

Theoretical Background. Upon its publishing in 1995 The Tunnel by W. H. Gass got more indignant than favourable press. There were valid reasons for the negative press on the novel. In the non-stop, 650 pages long lamentations of the protagonist the first readers of the novel read an attempt on revision of established views on WWII and Holocaust, on history metanarrative and family values.

\begin{abstract}
"Much of the resistance to The Tunnel expressed by its first readers centered around the dim distinction between author and his created narrator. Gass they charge did not distance himself clearly and sufficiently from the racist, sexist, vulgarian Kohler." [8]
\end{abstract}

Eleven years later, in the 2006 book of literary criticism A Temple of Texts W. Gass again confirms his practically lifelong passion for the Rilke's novel:

"Of the books I have loved ... there has been none
that I would have wished more fervently to have
written than tis intensely personal poem in prose,
this profound meditation on seeing and reading-
on reading what one has seen, on seeing what one
has read." [5]

One of the most straightforward instances of the negative criticism of the novel was Will 
Blythe's 1995 review titled Tunnel Vision. It is overall bitterness that the critic censures the book mostly for:

\section{"The Tunnel turns out to be the grand opus of entropy, the antiepic, the super sulk, the anatomy of failure, the pseudonarrative that peters out in a snit." [1]}

Gass's controversial novel has since got due scholarly attention and treatment and a scholarly accord can be observed in acknowledging the novel's high literary merits, the chief one being that of exploring hitherto unknown possibilities of the verbal representation of the referential, objective reality world. This verbal reproduction / delineation of everything that surrounds us, that makes us, that defines people, society and an individual attains in Gass's prose a new linguistic property, new expressive depth. This language-centered approach turns out to be instrumental in the novel, it opens up new, and beautiful, terra incognita in the fictional representation of life and things.

A succinct summation of William Gass's prioritizing the language in fiction to what the fiction says or strives to bring home to its readers is done by the writer Vince Czyz in his homage-giving article to pay tribute to the late William Howard Gass and his great contribution into American literature:

"Sentences, he maintained, are "containers of consciousness"; they are thoughts rather than representations of thought. The sentence, Gass asserted, if it is to outlive its maker, must have a soul, not "merely be a sign of the existence somewhere of one." It must find "in its drive and rhythm ... the verbal equivalent of instinct." He treated the "style and characteristic structure of the sentences that filled the novel ... as microcosmic models for the organization of the whole." This is not to say his stories and novels are plotless; rather, the stories he tells are not the prime movers of his fictions. His loyalty was to the words composing his text." [2]

The literary scholar Stanley Fogel singles the metafictive chararteristics of Gass's prose, his antirealistic damage - the rhythms and incessant alliteration, the showiness of metaphors. Also, the researcher specifies the undisputable influence on Gass of such eminent modern American writers as John Barth, Robert Coover, and Donald Barthelme as well as such writers as Nabokov, Jorge Luis Borges, Samuel Beckett, and Gertrude Stein.

"For Gass she [Gertrude Stein] is revolutionary because she shows how the language of the novel can be antireferential, can resist being a window that provides direct access onto the world." [7]
Susan Stewart in her contribution to a collection of academic research papers under the collective title Into The Tunnel explores the intertextual links of the novel with the European writers and philosophers. The first in this list goes Rainer Maria Rilke, while important parallels of the novel can be seen with the works Thomas Mann (Doctor Faustus), Goethe (Faust), Thomas Hardy, Proust, Lovelace, Paul Celan, Kafka. [10].

\section{Results and Discussion}

"Experimental fiction" is the definition W. H. Gass himself applied to his form and mode of writing. Seemingly clear at a first glance, this definition is too vague and imprecise when not clarified. In modern literature, experimental fiction is associated, first and foremost, with denouncing classical realism, transgressing its time-honoured canons, marginalization of narratives and metanarratives, erasing the dichotomy of proper and improper, decent and indecent, sacred and profane, sublime and mean, honourable and dishonourable. One thing when these antinomies are put on the same footing in a literary research paper and quite another thing when we see this approach implemented in a literary work. In some of its narratives, discourses and fragments The Tunnel manifests this same-footing approach.

There is one more principal distinction of experimental fiction. It explores the boundaries of the linguistic means of delineating of whatever the author chooses for the content of his fictional representation. What is unquestionably recognized as William H. Gass's outstanding achievement in The Tunnel is the language of the text, the language which does have a parallel life, a life of its own, even one may say autonomous status when compared to or contrasted with the subject matter which the chosen language means represent. It is an obviously original and fundamental 'trademark' of The Tunnel not shared by a majority of postmodernist fiction. The given novel abounds in what we may call reduced-to-language fragments. These are passages giving extended delineations, the descriptions featuring entirely new properties of the things, phenomena, abstract notions and concepts. The famous descriptions of the elements and objects - tornado, dust, barns, windows, blackboards and many others the numerous typographic innovations, a big stock of limerics, observance of rhythmic prose patterning, systematical persistent alliteration exemplify what we have termed "reduced-to-language" fragments.

Enumerating things, making long lists of their differently worded names and properties belongs to the top staples of Gassean method and techniques in the novel. Can this commitment to exhaustive characterization of an object or phenomenon be regarded as a Rilkean literary staple which was picked up and appropriated by W.H. Gass? 
To prove or disprove this let us examine $\mathrm{R}$. M. Rilke's The Notebooks of Malte Laurids Brigge for the ways of describing the things which arouse the book's protagonist's curiosity to such an extent that he plunges into characterizing them in all their versatility while attributing them an e $x$ i s $t$ e $n t i$ a, imparting them a conscience of their own. Rilke's predilection to reimagining and personifying the thing (das Ding), writing something like self-contained stories about them can be seen in the fragment dealing with the sound made by a falling lid of a tin:

"Nearly everyone will be acquainted with the noise any round tin thing makes--say, the lid of a tin-when it slips from your grasp. Usually it doesn't actually make a very loud sound when it hits the floor; just a short one before it rolls along on its edge and it doesn't offend until it stops travelling forward and rocks and clangs before coming to rest. Well, that's the whole story; some such tinny object fell next door, rolled, then, after pitching about at certain intervals, lay there." [9]

The text of the Gass's novel simply abounds in suchlike descriptions of things. For all the similarities in the delineation of things by both writers, Gass's approach acquires an extended essayistic form like in a five-page description of the classroom blackboard. The writer, that is the book's narrator and protagonist William Frederick Kohler, opens his description, with:

"Three spaces mater in my life: they are my Trinity: the pane of the window, the white of the page, and the black of the board. I would like to have said, the body of my beloved, but I can't." $[6,311]$

It is not the functional aspects of the blackboard that attract William Frederick Kohler's, the book's protagonist's, attention and speculation. It is immaterial spiritual transcend linkage of Kohler the history professor to his tool-of trade, the blackboard, that triggers off his lengthy speculation on what the blackboard meant for him in his professional life:

...As useful as it is in these several ways, none of them is the source of its fascination for me. The board is at once the surface of a pit-black sea and a bleak opening onto all our inner spaces. It is a brink of what we are and hence a horror; nevertheless it is so simple, unassuming, so solid as a symbol, that the feeling it gives me is one of reassurance... [6, 311]

What unites the two quotations, definitely including their wider context, is both writers reliance on their power to impart a new, verbal, fictional life to inanimate objects, to switch them on into the orbit of their heroes' fictional life, to show them in a new descriptive light. This capacity of fusing the world of things into the literary character's life and psychology predominant in William Gass's writing method and mode, it has become the writer's literary staple, and the origins of the latter lie in Rilke's prose the impact of which on W. Gass was invariably admitted by the American writer.

Reflectiveness of the authorial and protagonist's voices, these voices often merging into one, permeates both books. Sometimes this reflectiveness is unfolded by means of the stream-of-consciousness narration and sometimes in the essayistic form. When in Gass's novel we come across a passage like

"The things that recollect us. Historians should keep
our vagrant habits in mind, for, on the whole, we
don't remember the crowning of kings or financial
panics - whatever they count as history - but
tacky key rings made of building products instead,
laminated four-leaf clovers and cellophane sacks
whose interiors marshmallows have powdered, jars
containing jellybeans..." [6,586]

we can observe evident traces of similarities with Rilke's meditation and reflectiveness in The Notebooks of Malte Laurids Brigge:

For centuries now things have been looking on at them. Small wonder that they're depraved, that they lose the taste for their natural, deep purpose and want to exploit existence in the way they see it exploited all around them. They make attempts to shirk their duties, they become listless and slipshod, and people are not at all surprised when they catch them running riot. People know that very well from their own experience. [9]

The next obvious convergence of Gass's and Rilke's literary techniques can be seen in employing inserted stories and letting the narration go astray from the theme, scene or description being unfolded at the moment. The story of Malte's next door neighbor, Nikolai Kusmitsch, at the lodgings during his stay in St. Petersburg (a fact of Rilke's biography) and the story of an immigrant family in "Being a Bigot" section in The Tunnel illustrate this inserted story technique perfectly.

An intertextual parallel can be drawn between the chunk of the Rilke's novel describing the neighbours people chance to have, and be either indifferent to or curious and mystified with, and the fragment in The Tunnel's seventh philippic The First Winter of Our Married Life.

Rilke:

There exists a being that is perfectly harmless; if it comes into view you hardly notice it and you instantly forget it again. However, should it somehow invisibly invade your hearing, it starts to develop, 
it creeps out of itself, so to speak, and one has seen cases where it has got as far as the brain and has thrived in this organ with terrible effect resembling pneumococci in dogs that enter through the nose.

This being is your neighbour.

Now, because I'm never long in a particular place I've had countless neighbours; neighbours above and below me, neighbours on my right and on my left, and sometimes at all four places together. I could easily write the history of my neighbours; it would take a whole lifetime. [9]

\section{W. Gass:}

After that we tiptoed, grew footpads,became stealthy. When we heard their closet hangers jangle like cattle on a hill far away, we shut our doors so silently the latches snicked like a rifle. I had heard his heavy smoker's hack '(hollow, deep, and wet as a well), so we took multivitamins to ward off coughs, then syrups to stifle them when colds caught us anyway, and increasingly felt like thieves and assassins.

Our ears were soon as sensitive as a skinless arm, and we spoke in whispers, registered the furtive drip of remote taps. It was like living in front of a mike as you might pose and smirk in front of a mirror. We heard ourselves as others might hear us; $[6,336]$

Both novels share the protagonist's personal history of reading habits and preferences as well as reflections on the craft of writing. William Gass must have definitely been impressed and influenced by the corresponding passages in Rilke's largely autobiographical novel because The Tunnel features this narrative on a prominent scale.

In The Tunnel, the homage of William Howard Gass to Rainer Maria Rilke is very prominently represented, in the way of intertextual parallels. in the twelfth, final philippic of the novel. This philippic bears an overall title An Outcast on the Mountains of the Heart, and has a (sub)section of the same title. The philippic's name is a reminiscence of the title of Rilke's famous 16-line poem "Ausgesetzt auf den Bergen des Herzens". The poem's title has been variously translated as "An Outcast on the Mountains of the Heart", "Mountains of the Heart" and under other titles.

The subject-matter of the section is the protagonist's recollections of his frustrated childhood. Kohler's revulsion, indignation, anger, unforgiveness form a hatred discourse of alarming intensity. His meticulous racking of his memory appears to have no other purpose but verbalize every possible fault with them, blame them for their revolting predilections and vices, for their neglect of him, their failure to avoid not being lame ducks. What strikes the reader most here is the protagonist's (and, evidently, the writer's) utmost and ruthless frankness with which he writes about his parents and relatives. With William Frederick Kohler this ruthlessness does not appear to have diminished with years, being a grown up man he still can't help loathing the aunt of his childhood.

So, An Outcast on the Mountains of the Heart philippic makes the saddest reading in the book, its narrative sometimes transgressing, or rejecting, what we know all as pity, sympathy, mitigation, tolerance, getting into someone else's shoes and the like. The intensity of the hostility on the part of William Kohler the little boy to his aunt, and even to his Granny, is very masterfully, brilliantly reproduced in a number of descriptions and portrayals which by their linguistic expressive form put that hostility, if not hatred, to the narrative background:

If she had opinions she never offered them, and the decisions she had to make were announced only when necessary and couched in careful negatives: she didn't think she'd mind not having refused that job; perhaps the weather didn't wholly prohibit a picnic; she didn't hate the dress she'd bought although she'd bought it because it was on sale. $\langle\ldots\rangle$ Nor did you have to eat the cake she'd baked, but here it was, nevertheless, not her favorite sort certainly, but only what the larder made possible, though fortunately of so few ingredients as not to lower the stock by any appreciable amount, after all, who'd miss such negligible items; [6]

The text of the Aunts section as well as the text of the next one, Mother Makes a Cake, afford this kind of humiliating descriptions in plenty. One may wonder what made the writer to craft such despicable portrayals of a person, the person being the narrator's relative, and one may not agree with an opinion that such hostility discourse has its roots in the writer's autobiographical parallels. For the most part, the roots and causes must lie somewhere else, in the ambivalent aesthetics of experimental fiction largely denying the moral ends of fiction.

But in what relation does the content of The Tunnel's last philippic stand to the issue of Rilkean borrowings in the novel? At this stage of our research we come to a conclusion that this relationship, in regard of the first two sections of the philippic, is mostly reduced to rendering an overall slant of the sections by means of the Rilkean metaphor. "An Outcast on the Mountains of the Heart" metaphor is one of a person's solitude, alienation, acutely felt desperation over the former harmony of heart / psyche and soul and being. The Rilkean scholars suggested a number of interpretations of this outstanding poem and its reverberation in Gass's novel but the scope and character of the poem's impact on the novel is so significant and complicated that it remains an issue of literary research. With a prospect of continuing 
the research undertaken, here we confine ourselves only to quoting one of the most accurate translations of Rilke's poem into English:

Cast out on the heart's mountains. See, how small there, / see: the last habitation of words, and higher, / but also so tiny, one last/farmstead offeeling. Recognise it? / Cast out on the heart's mountains. Rock ground / under the hands. Something / doubtless blooms here: from the dumb precipice / an ignorant plant is flowering singingly forth. / And the person with knowledge? $A h$, the one who began to know / and is silent now, cast out on the heart's mountains. / Doubtless many a thing walks there / with a clear consciousness, many a safe mountain beast / wandering, lingering. And the great secure bird / circles around the summit's pure renunciation. - But / insecure, and here upon the heart's mountains... [3]

\section{Conclusions}

In this paper, the intertextual register of William Howard Gass's novel The Tunnel has been treated. The gamut of the novel's intertextual links and parallels is wide and varied. It is represented by an impressive number of writers and literary sources ranging from Goethe to Thomas Mann to Paul Celan to Paul Valery, from Thomas Hardy to Gertrude Stein to John Barh.

A major set of intertextual parallels and influences of Gass's The Tunnel falls on Rilke's prose works and poetry. William Gass's lifelong literary ideal to strive for was Rilke's The Notebooks of Malte Laurids Brigge. Equally fascinated was W. Gass with the vast scope of Rilke's poetical works paying the largest tribute to Rilke the poet by having written the book Reading Rilke: Reflections on the Problems of Translation, and having translated ten Duino Elegies himself.

This paper has dealt with the problem of identifying the chunks and fragments of W. Gass's novel The Tunnel which could be traced back to Rilke's texts. Unraveling the said problem was not an end-in-itself for this research, this task went handin-hand with establishing and exemplifying William Gass's literary staples, comparing convergencies and differences between both writers' visions of literature, their specific modes of writing, their understanding of the relationship of the true, real and the fictional.

We have established that both writers share a principal vision in respect of representation of the things, material world finding them to be as noteworthy objects for description and speculation as the world of human feelings, conflicts, passions. To this end we have compared Rilke's description of what 'life' a tin of a lid, and other things live and Gass's five-page-long description of the classroom blackboard and its assumed links and impact on the protagonist of The Tunnel. The juxtaposition of the two descriptions testifies to Rilke's angle of literary vision having influenced that of W. H. Gass.

The next instances of Rilke's influence on W. Gass's fictional writing have been examined in respect of the following: the narrative device of inserted stories, The Tunnel's philippic The First Winter of our Married Life having obvious bearing to the Rilke's Notations' fragment on the neighbours, both books' protagonists' personal history of reading habits, likes and dislikes, The Tunnel's final philippic Outcast on the Mountains of the Heart. This philippic accumulates much of the manifold set of Rilkean influences which William H. Gass imbibed and, to his credit, did not simply borrow or imitate but refashioned to a high degree of genuine, authentic, admirable prose.

Finally, the research which results have been outlined in this paper requires further steps to be taken on the way of examining a more inclusive range of Rilke's parallels in W. H. Gass's novel The Tunnel.

\section{REFERENCES}

1. Blythe, Will. Tunnel Vision.

https://classic.esquire.com/article/1995/3/1/tunnel-vision

2. Czyz, Vincent. Arts Remembrance: "Purified Modernist" William Gass - A Wizard of the Word. https://artsfuse.org/167016/remembrance-purified-modernist-william-gass-a-wizard-of-the-word/ 3. Coates, Paul. Words After Speech: A Comparative Study of Romanticism and Symbolism. https://books.google.com.ua/books?id=j16wCwAAQBAJ\&dq=rilke\%27s+the+mountains+of +the+heart + metaphor\&hl=ru\&source=gbs_navlinks_s

4. Coetsee, J. M. Going All the Way. https://www.nybooks.com/articles/1999/12/02/going-all-the-way/

5. Gass, William H. A Temple of Texts.

https://books.google.com.ua/books/about/A_Temple_of_Texts.html?id=AQVQjI7ngVoC\&redir_esc=y

6. Gass, W. H. (2007). The Tunnel: Dalkey Archive Press. Second printing, 652 p.

7. Fogel, Stanley. William H. Gass.

https://www.thefreelibrary.com/William+H.+Gass.-a0138397372

8. Kellman, Steven J. (1998). "Boring through The Tunnel”. Into The Tunnel. Readings of Gass's novel. Edited by Steven G. Kellman and Irwin Malin, Newark: University of Delaware Press, 172 p. (p. 35) 
9. Rilke, Reiner Maria. The Notebooks of Malte Laurids Brigge. Translated and edited by Michael Hulse. Penguin Books.

https://ru.scribd.com/doc/255505293/The-Notebooks-of-Malte-Laurids-Brigge-Rainer-Maria

10. Stewart, Susan. (1998). "An American Faust": Into The Tunnel. Readings of Gass's novel. Edited by Steven G. Kellman and Irwin Malin, Newark: University of Delaware Press, 172 p. (36-52 pp.)

11. William Gass. The Art of Fiction No. 65. Interviewed by Thomas LeClair.

https://www.theparisreview.org/interviews/3576/william-gass-the-art-of-fiction-no-65-william-gass

Дата надходження статті до редакції: 25.04.2019.

Прийнято до друку: 14.05.2019. 